\title{
The Sydney Organisng Committee for the Olympic Games (SOCOG) Olympic 2000 National Education Program
}

\section{'Developing International Understandings through Olympic Education'1}

\author{
Susan Crawford \\ Program Manager of The Olympic 2000 National Education Program, SOCOG
}

Austraria

1 Paper to be presented at the International Conference for the 20th Anniversary of the Japanese Society of Sport Education, 17-19 November 2000, Osaka, Japan.

Address for correspondence:

Sydney 2000 Olympic Headquarters

235 Jones St Ultimo 2007 NSW

Austraria

Tel: $+61(2) 92972596$

Fax: $+61(2) 92972818$

E-mail: susancrawford@au.gateway.net

オーストラリアの10,500校、320万人の生徒を対象にした「オリンピック 2000 全国教育プログラム」のマ ネージャーとして、3年間、その計画、展開、実施に努めた。同プログラムは、オーストラリアの全教育機 関を対象とし、学校の教育課程に適応するように作成、一方、メディアを活用するなどして、オリンピッ ク理念の理解と、国際理解を促進するよう計画した。

オリンピック新聞「O-News」を3歳から12歳までの全児童に配布し、オリンピックの理解をはかった。ま た全学校に、CD-ROMやビデオ教材「aspire」を配布する一方で、インターネットでも教材「Kids」を立ち 上げ、オリンピックの理念、スポーツ、環境、異文化理解の教材が提供された。そのほか、生徒の描いた 絵を選手村の部屋に貼り、選手が生徒に手紙を送るようにポストカードを準備し、実際に 11,000 人の生徒 が、ポストカードを受け取った。これらのオリンピック教育の具体的な成果は調査中であるが、「オリン ピック 2000 全国教育プログラム」は、個人やグループにおいても、オリンピックを教材にして、国際理解 を促進できることを示したという意義を持ち、今後もシドニー・オリンピックの遺産として生き続けるも のと確信する。

For three years I have been responsible for the design, development, management, delivery and evaluation of the SOCOG National Education Program for the 10,500 school communities in Australia. I wasn't anticipating the exciting personal and professionally rewarding journey when I com- menced at SOCOG as Manager of the Olympic 2000 National Education Program in October 1997.

Designed as a dual Education and Communication Program, my association with the Program has taken me along many pathways, all of them unique and thrilling, and I am particularly honored to have 
been invited to your wonderful country and specifically to the International conference of the 20th Anniversary of the Japanese Society of Sport Education here in beautiful Osaka.

Respecting the essential role of education in modern Olympic history, education was given a place in SOCOG's structure, resource allocation and plans which facilitated the development of the Olympic 2000 National Education Program. It also reflects an understanding of the significance of education in terms of the potential for a legacy of the promotions of international cultural understanding from the 2000 Games for our nation's youth.

As we are in the evaluation stages of our Olympic and world-first Olympic 2000 Education Program it is pertinent that I commence by setting out the objectives and then perhaps leaving it up to you to draw your own conclusions as to how well we may have succeeded in terms of promoting the Olympic Ideal of Development of International Understandings as the Program has progressed. We currently have a Professor from Sydney University researching a formal Program evaluation for us, and this will be available to interested parties mid-2001.

\section{Objectives of the Olympic 2000 National Education Program}

In 1997 we set out to encourage the youth of Australia to understand and embrace the spirit of the Sydney 2000 Olympic Games, as well as building in all young Australians a sense of ownership and enthusiasm for our Games in 2000. At the same time, we set out to maximise Olympic-related education benefits through the incorporation of Olympic themes into all key learning areas of the school curriculum from Kindergarten to Year 12.

In essence, a huge brief given the demographic and multicultural nature of our nation, along with the target age range of every 8 year old to 18 year old in our country.

\section{Defining Features of the Olympic 2000 National Education Program}

We believe our program has been unique for a number of reasons:

(1) firstly, it sought to target and touch EVERY school community in Australia;

(2) secondly, it integrated educational aims and objectives with those of community relations and communications to grassroots Australian community;

(3) thirdly, every strategy integrated educational principles and perspectives and linked to key curriculum outcomes which were relevant to every school student in the target range in Australia, regardless of state or school system;

(4) fourthly it is based on a variety of media channels of communication;

(5) fifthly, it has attempted to broaden the historical interpretations of 'Olympic Education' and make it more relevant to the youth in our contemporary society;

(6) and lastly, we developed a vision which would 'put Olympic Education' up front - which would draw the attention of national and international eyes to our resources, their delivery and our Program's participation levels amongst the youth of our nation. We set out to deliberately create an enduring legacy in the minds of our youth which would last well beyond the 2000 Games and into the next generation of young Australians.

In a sense, we had to ensure we approached and established a degree of national understanding about the principles underpinning Olympism amongst our school communities, before even hoping to effect an increase in 'international and global understandings' through our Program.

I'm sure, that prior to 1997, many students and teachers in Australian schools had no idea about what Olympic Education was or could be. Even though I became involved in Olympic Education as a High School Teacher when Australia was preparing for the bid in 1993, I found myself without a practical 
philosophy of Olympic Education when I commenced working in my first full time Olympic Education Promotions role. So, I went out in search of one.

\section{Olympic Education - A Personal Philosophy}

I commenced by researching how other Olympic Committees and sport-related organsiations interpreted Olympic Education, and I found that Olympic Education was really a multidisciplinary field made up of many different components, all equally important, some areas having more relevance to some than others. For example, the sporting enthusiast will always say 'sport' when asked what Olympism is about. Those with an affinity for the Arts will always identify firstly with culture. Reality is, Olympism is based on four pillars - sport, education, culture and now environment. In between these four pillars, there is much that can be melded to fill out a more complete picture as to what Olympic Education can be, and further how it becomes more relevant in contemporary society, bringing with it a power of relevance for increasing international, inter cultural and global understandings within and between nations.

My personal philosophy of Olympic Education is grounded in the interpretation and the application of the key Olympic themes, concepts, messages ideals and spirit into teaching / learning contexts for the classroom and whole school community activities. Like a bridge, these themes and concepts can be linked to syllabus outcomes and used as exciting springboards for learning. In this paradigm, Olympic Education focuses on the melding of sport, culture, environment, technology, and such intangibles as traditions, having a go, personal and national pride, the pursuit of excellence, team effort and spirit, tolerance and acceptance, friendship and joy in effort and lots, lots more!

\section{Promoting the Olympic Ideals in our Key National Initiatives}

(i) O-News, the Olympic Student newspaper
In July 1998 the huge Fairfax newspaper publishing presses in Western Sydney undertook the largest print run anyone has ever embarked upon in Australia.

- it was an Olympic first! SOCOG's National Education flagship communication vehicle O-News, designed specifically as an education / information newspaper for the 3 Million Years 3-12 students in Australia, rolled off the production line. Since then we have distributed four more editions of O-News to every student in the target range group, via their school.

$O$-News addressed the key curriculum areas through sport, culture, technology environment and the other key Olympic themes, as well as providing an important avenue for the communication of SOCOG messages on ticketing, transport, volunteers, and other aspects of Games planning. All the stories, which supported curriculum outcomes for use in the classroom and projects, were not only an interesting read, but a fun publication for students and their families. Our progressive market research revealed students in schools felt that the approach taken by our Presenting Partner sponsor, the Westpac Bank in its advertisements promoting the Olympic Ideals and our athletes was very popular because the readers could relate positively to these important messages in their current youth context.

\section{(ii) aspire - the 2000 Olympic Games Resource for Australian Schools}

Secondly, aspire, the 2000 Olympic Games Resource for Australian Schools (comprising a CDRom, Teachers Guidebook, posters, video and Internet activities) was distributed to all schools in July 1999. Our aspire resource for Australian schools broke new ground in terms of use of multimedia in Olympic Education in the classroom. We wanted to ensure this resource is applicable and relevant to learners in the new millennium.

The CD-Rom contains a fun-filled navigable world which allows the students and teachers to explore Olympic Education through the five key 


\section{スポーツ教育学研究 第 20 巻 第 2 号 平成 12 年 11 月}

themes of (i) Designing Sydney 2000; (ii) The Environmentally Friendly Games; (iii) The Athletes Games; (iv) The Cultural Olympiad; (v) Olympic Issues Past and Present. This fun navigable world also references the Internet site and the student newspaper components of the National Education Program.

The downloadable files on the other half of the CD-Rom addresses key learning outcomes across the primary and secondary curriculum and provides teachers with teaching ideas and strategies which can be used as presented or as 'springboards' for delivering an Olympic Education perspective to all school syllabuses.

The Teachers Guidebook gives direction to teachers as to the versatility of the Resource components, including how to use the teaching and learning ideas in relation to the CD-Rom navigable world, the posters, video and Internet projects.

In summary, the treatment of issues such as recording of political interventions, the historical involvement of Olympic nations in the Games and its multicultural and global perspectives have ensured the aspire resources have provided an enhanced platform for learning about global and international understandings across the curriculum in schools. Further, all aspects of the aspire multimedia resource, which directly link to national curriculum outcomes across all learning areas, has been widely implemented in Australian schools promoting the Olympic Ideals through the provision of practical learning ideas for students from 5 to 18 years of age.

\section{(iii) 'kids' - our internet presence}

This all encompassing 'Kids' area within the SOCOG web site is an engaging, fun and exciting place for kids (and big kids) to visit for learning and leisure. It features activities and games which have Olympic contexts and themes embedded in their design, as well as a large parents and teacher section which explains the Olympic 2000 National Education Program strategies and involvement opportunities for students and school communities. This
'Kids' section of the SOCOG Internet site is the Program's international face and invites the youth of the world to participate in some great interactive activities which are organsied into the Techno, World, Green and Sports Zones. This particular strategy sets out to invite participation in our Program amongst the youth of the world. Further, the 'World Zone' section is based on communications and sharing amongst individuals and school communities, both nationally and internationally.

\section{Enhancement Programs}

In addition to these key initiatives, there are numerous Enhancement Programs.

Amongst these, the 'share the spirit' Art Program is a joint SOCOG Consumer Products/Education Program, which invited students from across the nation to create artworks around the Olympic themes of 'Sport', 'Multiculturalism', 'Welcoming the World' and 'Friendship'. In 2000, his program alone had a participation rate of more than 54,000 students.

A natural follow-on from this Program has been our Welcome World Art Program which saw the preparations of over 11,000 of these artworks for hanging in the Athletes room in the Olympic Village. Each athlete participating in the 2000 Games had the opportunity to write and personally thank the student who created their welcoming piece of artwork, which the athlete will take home with them as a special memento of the 2000 Games. This Program has provided an opportunity for athletes from all Olympic nations to reach out and 'touch' with their words of thanks the youth of our nation.

The Language Services Program worked with National Education to develop a teaching resource 'En 2000 a Sydney' to target the French language curriculum. In this culturally complementary initiative a comprehension-based kit for teachers of French was developed in collaboration with the French embassy,

The Olympic Welcome Program provided a unique opportunity for host NSW primary schools and the 'national network' schools in each state of Australia 


\section{Crawford: The Sydney Organisng Committee for the Olympic Games (SOCOG)}

Olympic 2000 National Education Program

to be linked and establish friendships with both Australian and International Olympic teams competing in the 2000 Games. Schools throughout Australia studied the cultures and Olympic dreams and hopes of each of the Olympic nations. The highlight of the Program for the NSW schools is that school choirs sang a specially written song 'G'Day G'Day - You are the Heroes of the World' at the Official Team Welcome Ceremonies in the Olympic Village.

\section{Student Involvement in the Games}

Over 2,500 high school students were invited to be Escort Runners for the Torch Relay. The National Education Program supported the Torch Relay Team to ensure that local school communities had ownership of the selection of the student ambassador to represent their school.

Up to 9,000 students from across NSW were involved in ceremonies for the Games and approximately 2,500 students were directly recruited from schools to be volunteers in a various Games-time positions ranging from Court Personnel to Press Tribune Runners. Community spirit and international cultural understanding are the values held dearly by these young Australians who have dedicated their leisure and vacation time to supporting the staging of a successful Olympic Games. Their reward is being part of the Games and supporting the ideals of the Olympic Movement.

\section{In Conclusion}

It is afterall with the youth of our nation that we will leave the most lasting and real legacy of the 2000 Games.

What we will have remaining is a legacy of the Olympic 2000 National education Program in school communities throughout our nation once the euphoria of the Games dies down, will be the developed understandings, values and attitudes which have been changed because the youth of our nation had the opportunity to experience a sense of involvement in the 2000 Olympic Games.

The development of global and international understandings is a very important outcome we have targeted in the design and delivery of our National Education Program. Students in our schools from as young as 5 years have been involved in a range of experiences studying the cultures of Olympic nation; interacting with other cultures through our website activities; and forging personal communications in the Olympic Welcome Program as the choirs performed their special welcomes to the Olympic family and teams. There were cheer squads amongst the school groups in the audiences for the Games barracking for their linked nations in the Welcome Program; up to 11,000 students received a thank-you postcard from an athlete from another nation because their artwork was selected to be hung above their bed in the Olympic Village; and the list goes on.

The Olympic 2000 National Education Program will hopefully become a watershed in the historical records of Olympic Education legacies. It is timely there appears to be an increasing international comprehension about the importance of the link between education and youth and the Olympic Ideals and the potential positive power of the Olympic Movement in promoting international understandings amongst individuals, groups and nations.

As Program Manager of the 2000 Olympic National Education Program, I am proud to say I believe this legacy will be more enduring and of deeper worth and greater value than many other defining moments of national consciousness in Australia's past - or future. 